\title{
A Case for Transnational Law in Contemporary Times
}

\section{CB Soyapi*}

\section{P.E.R}

Pioneer in peer-reviewed, open access online law publications

Author

Caiphas B Soyapi

Affiliation

North-West University, South Africa

Email Brews.Soyapi@nwu.ac.za

Date Submission

21 April 2020

Date Revised

17 November 2020

Date Accepted

17 November 2020

Date published

20 November 2020

Editor Dr A Gildenhuys

How to cite this article

Soyapi CB "A Case for Transnational Law in Contemporary Times" PER/ PELJ 2020(23) - DOI

http://dx.doi.org/10.17159/1727-

3781/2020/v23i0a8197

\section{Copyright}

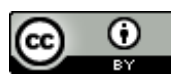

DOI http://dx.doi.org/10.17159/17273781/2020/v23i0a8197

\begin{abstract}
When Jessup first wrote about transnational law about 60 years ago, scholarship on globalisation had not started yet. It seems though that transnational law, as we understand it, is as closely related to and has been developing alongside globalisation. However, transnational law and its place in scholarship remains contested. In the context of this contribution, globalisation serves as the catalyst that has transformed the manner in which law is viewed nationally and internationally and as such presents the lens through which transnationality could be understood and conceptualised. The article shows that the transnationalisation of law is inevitable in a fluid and ever-changing society which demands answers and solutions to the increasing problems brought about by and through globalisation.
\end{abstract}

\section{Keywords}

International law; transnational law; transnational environmental law; globalisation. 


\section{Introduction}

In earlier works I have touched on aspects of the transnationalisation of environmental rights ${ }^{1}$ and transnational environmental law ${ }^{2}$ as emerging analytical frameworks. What I did not do in those works was to pay homage to the actual underlying theoretical framework upon which they could be understood. In this piece, with a view to outlining the contours and relevance of the transnationality of law, I seek to revisit the often-contested scholarly enterprise of transnational law. By no means will I delve into intricate aspects of what makes or drives transnational processes. The article also does not attempt to formulate a universal theory of, or exhaustively describe transnational law. Rather, the hope is that it fleshes out the context in which transnational law should be considered.

The first part of what follows provides the context in which this whole issue of the transnationalisation of law should be understood. It argues that through globalisation, a multiplicity of actors on the international stage has risen and new forms of regulation beyond the state are emerging. The second part briefly traces the concept of transnational law and surveys how the concept has evolved over time. In the third part, a brief exploration of law in the Westphalian state is undertaken. The line of reasoning followed here is that the state's exclusive control of law-making within its borders and on the international level is no longer intact. This is because forms of transnational law are emerging to address aspects of governance and regulation that are often hindered by the politics of government: i.e. the state. Lastly, I offer the example of transnational environmental law and the emerging concept of transnational climate law and governance to demonstrate that transnationalism in law has become a reality that could compliment the slower forms of law-making which states normally undertake.

\section{The context: a note on globalisation}

It would be challenging for one to approach the discussion of globalisation as a concept without preconceived ideas of what it is, given the attention it has been given in almost every facet of scholarship and the media. For that

\footnotetext{
* Caiphas Brewsters Soyapi. LLB LLM LLD (NWU). North-West University, Potchefstroom, South Africa. E-mail: brews.soyapi@nwu.ac.za. ORCID ID: https://orcid.org/0000-0001-6031-9206. I thank the anonymous reviewers for their comments and suggestions in improving the paper. All errors remain my own.

Soyapi "Emerging Transnationality of Environmental Rights".

Kotzé and Soyapi "Transnational Environmental Law".
} 
reason, there can be no universal description of globalisation, as it is understood differently in many circles (be they sociological, philosophical, legal or economic). ${ }^{3}$ This notwithstanding, it is possible to come up with some generic features of globalisation from the literature. Globalisation is described as:

... political and legal processes where complex multi-level governance structures emerge. National legal systems, losing their central position, interact with a large number of public and private actors on both supra- and sub-national levels in regulating individual and business conduct. ${ }^{4}$

Indeed, globalisation has been associated with the supposed "demise of borders" and it would seem from this description that globalisation is an evolving concept which has been involved in the transposition of norms across borders, the harmonisation of laws, including their divergence as well, and the creation of an environment that has seen the proliferation of non-state actors. Yet this is only one of looking at it, as elsewhere:

... globalisation is being used to describe a process of social change, a world being transformed so that there are greater contacts across national boundaries and growth or intensification of new networks and interdependencies. In other contexts it means the condition where geographical boundaries are rendered less relevant by the existence of these cross-border connections and arrangements. ${ }^{5}$

To be sure, then, acknowledging that globalisation seems to blur borders and shapes and views the world as a single market or society, in the legal sphere one could argue that an unavoidable result of globalisation is the fragmentation of laws. The implication of this is that old ideas of unity and system in law could become contested. ${ }^{6}$ The inevitable result is that law, as a social construct, has to adapt and realign itself along those fragmented and pluralistic lines. ${ }^{7}$ To this end, for law, globalisation could serve as an analytical perspective, a lens through which we can reappraise the law in a symbiotic world.

3 Shams 2001 Int'l Law 1591; Kotzé Global Environmental Governance 29; Venter Global Features of Constitutional Law 29. Also see Sutherland "Globalization and Corporate Law" 255, where it is noted that the concept is actually controversial, and the result is that it is impossible to give an uncontested definition of it. For general criticism and arguments for and against globalisation, see Venter Global Features of Constitutional Law 29-34.

4 Larouche and Cserne "Conclusions" 371.

5 Cranston 2007 Tex Int'l L J 600.

6 Cotterrell 2012 Law Soc Inq 503. Also see Michaels 2009 http://lsr.nellco.org/duke_fs/185 11.

7 See Boyd 2010 U Pa J Int'I L 503. For a full discussion of the fragmentation of laws in the light of globalisation, see Kotzé 2014 SALJ 548. 


\subsection{Globalisation as an analytical perspective}

A number of scholars observe that globalisation affects the manner in which we now understand law. They see globalisation as a lens through which one can view "the way legal norms are disseminated in an era when the prerogatives of territorially delimited nation-states ... have at the very least become less salient than they once were."8 Conceived in this light, globalisation is a lens through which to view the world because it helps us understand the social realities around us and the changes that come with them. ${ }^{9}$ Globalisation thus functions as an analytical perspective, rather than a process, since through the former we can appreciate contemporary societal phenomena. ${ }^{10}$ In other words, the world is now interdependent with the result that it is sometimes necessary to view the law in the context of the world as a single society. ${ }^{11}$ To be clear, when law is no longer conceived as state-centric but understood in a societal context, the process of globalisation (as an analytical perspective) could help us understand how and why law transcends national borders (this could be related to social phenomena) and manifests as transnational law. ${ }^{12}$

Globalisation as an analytical perspective allows one to view the state in terms of its receding power in favour of other emergent actors. ${ }^{13}$ It presents itself as a way of thinking of law in a global realm. This does not in any way signify the demise of the state ${ }^{14}$ or the denial of the "significance of the state as author, interpreter and enforcer of law", but it "opens up possibilities for conceptualising law in new ways." ${ }^{15}$ As a consequence, law - a social construct - invariably changes or adapts to globalisation. ${ }^{16}$ One could say that globalisation facilitates the processes of socio-legal change. ${ }^{17}$ If globalisation is indeed a part of social change, and if we accept that law is

See Berman "Introduction" xiv.

Kotzé Global Environmental Governance 33.

Kotzé Global Environmental Governance 33.

Kotzé Global Environmental Governance 33.

12 Also see Berman, who asserts that studying law and globalisation helps one to broaden the concept of what counts as law, and this inevitably allows us to recognise various non-governmental fora through which legal norms are disseminated. Berman "Introduction" xiv.

13 Shams 2001 Int'l Law 1597.

14 See Venter, who argues convincingly that the era of the state is not at an end, since international law is dependent on the existence of the state, while supranational institutions like the EU also rely on the defined borders of states and their abilities to organise laws. Venter Global Features of Constitutional Law 19.

15 Cotterrell 1997 Can J L \& Soc'y 76.

16 See Hund 2004 SAPL 32, who offers the contention that the globalisation of private law, "sometimes means the degree to which the whole world lives under a single set of rules."

17 Kotzé Global Environmental Governance 32. See further Shams 2001 Int'l Law 1599. 
a societal construct that is self-evolving and adapts to its environment, then it could be possible to argue that globalisation presents itself as an opportunity to view law in the transnational realm.

Suffice it to say that in the context of this short paper, globalisation is taken to have served as the catalyst that has transformed the manner in which law is viewed nationally and internationally, and as serving as the context for and driver of transnational law. Transnational law is thus a clear example in law of how globalisation is a force for change, because through transnational law it has become evident that state-centric views on law are no longer as intact as they were before. But what is transnational law and where does it fit in with the national and international regulatory space?

\section{The concept: transnational law}

Authors generally agree that conceptually, transnational law has its origins in the works of Jessup,,$^{18}$ as his Storrs lectures and his subsequent book, Transnational Law, have been the starting point for many who endeavour to grapple with the concept. ${ }^{19} \mathrm{He}$ used the term transnational law "as an expansive umbrella category" 20 for describing all law that is involved in international governance. Because of his conviction that the term "international law" was misleading since it suggested that one was concerned only with the relations between one state and other states, he framed his idea of transnational law as follows:

[I] shall use, instead of "international law", the term "transnational law" to include all law which regulates actions or events that transcend national frontiers. Both public and private international law are included, as are other rules which do not wholly fit into such standard categories. ${ }^{21}$

On the basis of this description it seems that transnational law could mean anything from actions to policies, treaties to model laws and usages that go

18 An American lawyer, Jessup wrote major works in international law even before he ventured into transnational law. He is considered to have argued fiercely against absolute sovereignty in that the interests of the international community as a whole were supposed to supersede those of individual states. See Brouder "Philip Jessup" 10. Thereafter Jessup became largely active as a United States diplomat and it is probably through his experiences abroad and his own involvement in international disputes that he developed his theory of transnational law. See Tietje and Nowrot "Laying Conceptual Ghosts of the Past to Rest" 18.

19 A number of scholars have openly acknowledged the contribution made by Jessup to the concept. These include Burley1993 AJIL 230; Koh 1996 Neb L Rev 186; Goode 1997 Int Comp L Q 2; Maniruzzaman 1999 Am U Int'l L Rev 660; Hathaway 2005 U Chi L Rev 473; Koh 2006 Penn St Int'l L Rev 745; Backer 2007 http://lcbackerblog.blogspot.com/2007/03/principles-of-transnational-law.html; Dibadj 2008 Stan J Int'l L 259; and Cotterrell 2012 Law Soc Inq 501.

20 Scott 2009 Ger Law J 863.

21 Jessup Transnational Law 2. 
beyond national borders. ${ }^{22}$ Transnational law, as perceived by Jessup, is thus flexible enough to be an umbrella term signifying rules and norms that cannot be categorised under national and international law. As a consequence, the term "transnational law" in Jessup's understanding has the advantage that there is a "larger storehouse of rules on which to draw" from; whether public or private,$^{23}$ for the purpose of settling disputes, effecting regulation or even seeking change. In fact, Jessup aimed to establish a jurisprudence that encompassed the law of cross-border social and economic phenomena more than international law did, since the latter could not. ${ }^{24}$ Jessup's work accordingly had an aura of clairvoyance as he attempted to start a dialogue about the processes and implications of globalisation many years before the debates even began. ${ }^{25}$

In recent times, however, the understanding of transnational law has broadened. For instance, Menkel-Meadow ${ }^{26}$ states that transnational law is "the study of legal phenomena, including lawmaking processes, rules, and legal institutions, that affect or have the power to affect behaviors beyond a single state border." The scholar offers a broad definition with the openended phrase "legal phenomena", which could also include non-state-actor rules and norms that are developed for use in multiple states/jurisdictions. Elsewhere, transnational law is understood to mean:

... across nations, as opposed to 'international,' which means between nations. The term 'transnational' therefore encompasses a larger universe of activity and interactions than does the term 'international.' When applied to law, for example, transnational law includes any law that has cross-border effect, whereas international law refers only to treaties or other law that governs interactions between states. ${ }^{27}$

22 While speaking on transnational commercial law, Kronke describes transnational commercial law as being a product of various means including "international treaties/conventions (i.e., binding instruments), model laws, contractually incorporated or 'codified' usages and rules, international restatements and pre-statements, and conscious or unconscious legislative or judicial parallelism-which lead to harmonisation of commercial law at the international level." Kronke 2005 Loy L Rev 288. Transnational commercial law is a derivative of the more general term transnational law and its sources could very well also be sources of transnational law. Jessup Transnational Law 15.

24 Jessup Transnational Law 15. Perhaps this is because classically, international law concerns only the relations between states, their rights and obligations on the international stage. See Karton 2012 Tilburg L Rev 276.

25 Brouder "Philip Jessup" 7.

26 Menkel-Meadow 2011 UC Irvine L Rev 104.

27 Hathaway 2005 U Chi L Rev 473. 
The differences in definition extend further, as is evinced by Mendenhall's ${ }^{28}$ description:

\begin{abstract}
What, then, is transnational law? In short, it is the pluralistic order of various principles and rules from divergent customs, cultures, and communities that draws its lexicon from competing philosophical discourses and not from topdown, coercive commands of states or sovereigns. It is a rejection of the power and modes of statism and a reversal of state-formation. It is an unsettling of borders and boundaries and a turn toward compromise and competition as means by which to settle disputes. The beauty of transnational law is that it serves the putatively 'liberal' interest of pluralism while serving the putatively 'conservative' interest of minimizing and circumventing government bureaucracy.
\end{abstract}

For Cotterrell, ${ }^{29}$ transnational law refers to "legal relations, influences, controls, regimes, doctrines, and systems that are not those of nation-state (municipal) law" but also "not fully grasped by the extended definitions of the scope of international law." In other words, apart from the "other rules" as noted by Jessup, modern concepts of transnational law have evolved to include intangible aspects like legal relations and influences, a development that indicates a shift from "government" to "governance". ${ }^{30}$ Taking stock from the varied descriptions noted, it would appear that in many instances transnational law is used in its literal sense with the "trans" meaning either beyond or across and the "national" referring to countries. ${ }^{31}$ But to better understand the concept and how it functions, it is necessary to review some characteristics of transnational law.

Transnational law is meant to resolve and/or address issues that cross national boundaries but which cannot be regulated solely by a single state. ${ }^{32}$ The result is that transnational law lies between domestic and international law, and overlaps them. As with transnational commercial law, which is "neither particular to nor the product of any one legal system" but a "union of rules taken from many legal systems", 33 transnational law is not a product of one state, nor does it belong to any one state. It has an "anational"34

\footnotetext{
28 Mendenhall $2011 \quad$ https://www.researchgate.net/publication/228227762_ Transnational_Law_An_Essay_in_Definition_with_a_Polemic_Addendum 7.

29 Cotterrell $201 \overline{2}$ Law Soc Inq 500.

30 See the discussion in Kotze and Soyapi "Transnational Environmental Law" 86-87. Mendenhall 2011 https://www.researchgate.net/publication/228227762 Transnational_Law_An_Essay_in_Definition_with_a_Polemic_Addendum 5.

32 Karton 2012 Tilburg $L \bar{R}$ ev 277.

33 Gopalan 2003 Am U Int'l L Rev 809.

34 Gopalan $2003 A m U$ Int'l L Rev 810, where it is stated that "[t]ransnational commercial law signifies a melding of rules that are completely 'anational' in character, and it derives its meaning through international usage and its execution by the business world". Therefore rules, in addition to actions and events, cross national boundaries. Also see Goode 1997 Int Comp L Q 2, who associates transnational commercial law
} 
character that is reflective of and reflects the global context in which law is being transnationalised.

There is, accordingly, considerable evidence that in recent times, the notion of transnational law has expanded to become increasingly complex, diverse and more particular at the same time. It has become an amalgam of rule systems, including hard and soft laws, whose foundational premise is its independence from the control/authority of any one state or community of states, by also creating a system of non-national and supra-national principles and rules. ${ }^{35}$ As we shall see below, this description accords the term its distinctive characteristic: a combination and a mixture of rules/norms from different levels that are all available not as replacements/alternatives for existing laws, but as augmentations that fill gaps, and sources for reform and the further development of law and policies in a globalised world. ${ }^{36}$

\section{Transnational law in the Westphalian system}

At this point it is necessary to briefly touch on how transnational law relates to law as conceived in the Westphalian system. As a caveat, the brief discussion that follows is far from comprehensive in detailing with the theory of law and its characteristics. This section is meant to achieve only two goals: to give an overview of what law has been generally understood to be and why that is so, and to discuss how transnational law fits within such an understanding.

\subsection{Law as a "state" construct}

The debates on what counts as law date far back, confirming that the law is of itself a human construct, designed by and for humans in society. In other words, law is a regulation of social conduct. ${ }^{37}$ According to Black's Law Dictionary, law is "that which is laid down, ordained, or established... . That which must be obeyed and followed by citizens, subject to sanctions or legal consequences". ${ }^{38}$ In some ways, this is an affirmation of the positivist line of legal reasoning. ${ }^{39}$ As Berman argues, positivists consider law to be a

with the term "anational" and also notes that apart from rules and actions, events also cross national boundaries.

35 Kotze and Soyapi "Transnational Environmental Law" 82.

36 See section 5.3 below.

37 De Garay 1941 Notre Dame Law 263.

38 Black Black's Law Dictionary 1028.

39 Converse to the implications of the positivist take on law, the natural law philosophers would conceive law outside the paradigms of lawmakers and its enforcement, since these came at a later stage in the development of human societies: the "essence of 
body of rules posited by lawmakers to effectuate their will and policy; which is enforced through coercive sanctions by official authorities. ${ }^{40}$ In this context, what counts as law cannot be separated from the lawmakers, the official enforcers and the enforcement itself. One could almost state that law cannot be thought of outside these paradigms. By implication, then, law in the modern state is inseparable from the institutions responsible for creating it and enforcing it. But for these institutions to work, one scholar notes, there must also be a body of substantive law, whether judicial or administrative (for example, law of contract or law of delict) and a judicial process which upholds the legal order. ${ }^{41}$ This description presupposes the existence of a highly organised society that is arranged along political lines and territorial boundaries; better known as a nation/state. Could it be possible, though, to speak of law without a state? Can there be law without a parliament or a judiciary to enforce it? ${ }^{42}$

The state has been at the centre of both politics and law, as traditionally the state has been associated with regulation. ${ }^{43}$ According to Venter, ${ }^{44}$ the world, even in the $21^{\text {st }}$ century, has been operating on the premise that "sovereign nation states are preordained characteristics of humanity and essential for the establishment and maintenance of public order" on all levels: from the family level to the global level. Evidently, in many societies law is that which is made by a legislature, with the result that anything else struggles to gain legitimacy as law. The prevailing and settled belief is that law has to be democratically legitimised and made by governments. ${ }^{45}$ Calliess $^{46}$ takes it further and concludes that the state subjects "all forms of

law is not its political dimension but its moral dimension." Berman 2005 https://papers.ssrn.com/sol3/papers.cfm?abstract_id=666143 6 .

40 Berman 2005 https://papers.ssrn.com/sol3/papers.cfm?abstract_id=6661436.

41 Berman 2005 https://papers.ssrn.com/sol3/papers.cfm?abstract_id=666143 3-4.

42 There are obviously jurisdictions that have a form of common law, which is usually the product of precedent and settled practice/common law. On the international level, both judicial decisions and settled practice are already established forms of law under Article 38 of the Rome Statute of the International Criminal Court (1998). Consequently, such common law is not included in this discussion.

43 Jessup Transnational Law 1; Bernal 2011 New Polit Sci 155; Quack 2007 Organization 645. Zumbansen states an assumption associated with law - that it has a territorial connection to a politically institutionalised system of rule creation, implementation and adjudication (he mentions that in Europe this is distinctly called the state-law nexus). Zumbansen 2011 https://www.wzb.eu/system/files/docs/ tsr/cgc/zumbansen2012definingthespaceoftransnationallawwzbhu.pdf 44.

44 Venter Global Features of Constitutional Law 12.

45 Calliess 2007 Ind J Global Legal Stud 473. A concession is made here that there are instances where binding law results from undemocratic or autocratic regimes. For this discussion, these are not considered within the meaning of "democratic legitimacy".

46 Calliess 2007 Ind J Global Legal Stud 473. See also Teubner 2002 Eur J Soc Theory 206 where it is stated that "[r]ulemaking by 'private governments' is thus subjugated under the hierarchical frame of the national constitution which represents the historical 
non-state law to different methods of degradation, namely incorporation, delegation, and deference." Put differently, if law is not incorporated or delegated and thereafter backed by sanction and not made by government, then such law is questionable and ultimately perceived as being illegitimate.

In their study of non-state ordering in South Africa, Nina and Scharf ${ }^{47}$ found that there is some kind of selective acceptance of other laws within states:

The state has historically defined the limits of that other sphere, and also defined its future trajectory. But the state's reaction to the other law varies greatly, depending on time and circumstance: sometimes it sees the other law as complementary to its ordering agenda and tolerates it without incorporating it. At other times and circumstance the state takes a dismissive and repressive stance towards the other law and attempts to discredit and destroy it.

Indeed as some scholars have found: "[t]he final word always rests with state law; whatever it fails to authorise has no prospect of recognition especially within a democratic state". ${ }^{48}$ In yet another argument it is posited that if law is not prepared in a practical manner, and if it does not have coercive means to secure its performance, then it is like "justice without her sword". 49 To the extent that any rule or law is not dependent on the state for its enforcement, then according to the above arguments such rules lack the essential character of law.

To underscore the power and the privilege states have in making law, one scholar notes the following:

The distinction law/non-law is based on a hierarchy of legal rules where the higher rules legitimate the lower ones. Normative phenomena outside of this hierarchy are not law, just facts. The highest rule in our times is, after the decline of natural law, the constitution of the nation state which refers to democratic political legislation as the ultimate legitimation of legal validity. ${ }^{50}$

Taking this line of argument further, it is clear that even international law itself is centred on states, since international law concerns the rights and

unity of law and state." See further Michaels 2007 Ind J Global Legal Stud 461, where it is observed that state law treats non-state law in a special way: "it 're-states' these norms by translating or even transposing them into the semantics of its own system."

$47 \quad$ Nina and Scharf "Introduction" 2

48 Calliess 2007 Ind J Global Legal Stud 476. Also see Cremades and Plehn 1984 BU Int'l $L J 324$, who argue in relation to transnational commercial law that "given the world's present political structure, in particular the overwhelming power of the nation state, any so-called non-national legal system can only exist with the sponsorship, or at least tolerance, of nations."

49 De Garay 1941 Notre Dame Law 266.

50 Teubner 2002 Eur J Soc Theory 206. Also see Kronke 2005 Loy L Rev 287, where it is stated that international organisations like the International Institute for the Unification of Private Law are bureaucracy driven. 
obligations of states. ${ }^{51}$ International law is law because states agree on it and authorise it. ${ }^{52}$ It is for this reason that international law, much like national legal systems, cannot be conceived of without states being involved. ${ }^{53}$ What this means is that any system of law that is not state or international law suffers from what Michaels ${ }^{54}$ calls a "competitive disadvantage," given the more functional and institutional support state law has.

\subsection{The consequences of/for law in a transnational context}

Given the embedded and long-established dominance of the state in law making, could there be a way to rethink/reimagine law-making? Consider the following question posed by one scholar: "Can the concept of law, endlessly refined and disputed in legal philosophy, be made to embrace legal transnationalism; that is, law no longer understood in its 'central case' as being state law?"55 Arguably, when we start thinking transnationally, we become liberated and can then "venture beyond long-established, perhaps stifling, conventions about what constitutes law and how to study it, into a less structured environment." 56 In other words, through transnationalism in law we are invited to see law in terms of its role in society, which could be productive for reconceptualising law, given that law is a reflection of society and its changing structure. ${ }^{57}$ In this globalised world, then, the state is simply a part of a society, which could now be conceived as a "world society". ${ }^{58}$

51 SeeTwining "Implications of 'Globalisation' for Law as a Discipline" 46, who sees state laws and international law as the Westphalian duo.

52 Meaning it cannot operate without the consent and recognition of nation states. Also see Berman, who states that traditionally international law is narrowly associated with the official acts of governmental bureaucratic entities which has resulted in the idea of international law itself increasingly becoming insufficient to capture the scholarly approaches that have been emerging. Berman "Introduction" xiv.

53 It has been suggested by some authors that transnational law itself ostensibly emerged "from the limits of international law". See Dibadj 2008 Stan J Int'l L 256.

54 Michaels 2007 Ind J Global Legal Stud 462.

55 Cotterrell 2012 Law Soc Inq 504.

56 Heyvaert and Etty 2012 TEL 4.

57 See Zumbansen 2011 https://digitalcommons.osgoode.yorku.ca/cgi/viewcontent.cgi? article $=1065 \&$ context $=$ clpe 3 .

58 Zumbansen $2011 \mathrm{https}: / /$ digitalcommons.osgoode.yorku.ca/cgi/viewcontent.cgi? article $=1065 \&$ context $=c l p e 3$. This is in direct contrast to a society or community in the narrow sense, as these are usually demarcated along borders. (Here, a society represents a grouping according to state borders.) In such cases, each society has its own views on law in the same way that each state has its own laws. Cotterrell 1997 Can $J L \&$ Soc'y 79. It follows then that a community in the sense that Zumbansen is referring to must be understood in the wider sense as a "world society". 
Law is self-evolving and is moulded by its environment simply because it must and does change in response to such an environment. ${ }^{59}$ If our current environment/society is now globalised, and if law is a societal construct, then as a self-sustaining and self-evolving system that changes according to its environment, law is no longer only a product of political compromise but also one that is largely driven by society. ${ }^{60}$ In a transnational context then, law is not about states, but about the global society and its needs. This however, raises important issues relating to the legitimacy of any law (especially in this case, transnational law) that is not state law (and dependent on a parliament). The most probable cause for this is because there are no checks and balances, forms of accountability (there is a lack of sanctions and enforcement thereof) and no demos to elect the legislator that must "make" and enforce such law. ${ }^{61}$ However, in defence of rules, norms and principles (law) not created by democratically elected parliaments, Perez $^{62}$ argues that the question of legitimacy could be approached from a:

[F]unctional or substantive perspective: to the extent that a transnational norm promotes the common good, it should be seen as legitimate. From this perspective, the process leading to the adoption of a certain norm is not relevant to the question of its legitimacy. Under this account, democracy has no role in the creation of legitimacy: the question is rather which set of criteria constitutes the best expression of the common good.

This apt analysis by Perez looks good for non-state actor rules and norms. In a way it also challenges the politics that is often associated with law, in

59 See Berman "Introduction" xv, who indirectly alludes to the societal touch the law has in the following statement: "Accordingly, legal scholarship emphasises both how people think about law in their daily lives and (more subtly) the ways in which largely inchoate ideas about the law can affect decisions they make."

60 De Garay notes that there must be a norm that informs the law; either juridical or societal (De Garay 1941 Notre Dame Law 267). Consider for example the case of environmental rights. Some states do not recognise or provide for them while international law does not provide for them in any treaty or convention. However, their legitimacy could be derived from the norm that informs their existence; their purpose, viewed normatively gives them credence with the result that it could be possible to argue in courts for the right to a healthy environment even though it is not specifically constitutionally protected. The norm behind them is the right of, or the entitlements of "society" in the broad sense to a healthy environment. If one considers that legitimacy is less the result of some logical deduction and more the product of practice and narrative, then it is possible to refocus the understanding of law in a transnational context along the lines of society's experiences.

61 See Ong 2010 Nord J Int'I L 71, for the view that rule-making and standard-setting by transnational and non-State actor networks are marred by the "perceived lack of transparency and hence accountability."

62 Perez 2003 Ind J Global Legal Stud 28. Also see Ong 2010 Nord J Int'I L 72, where it is argued that some non-state actor rules like the Equator Principles are approved through the active participation of the entities that will eventually implement the standards. This suggests that where the responsible parties or the concerned entities are represented, then concerns about transparency might not be legitimate. 
that the common good can be societal in nature rather than political. As noted above, law is a reflection of society and if, for the common good, nonstate actor rules are created, their legitimacy could be weighed not in formal ways but in the light of their ability to express a common good. To further provide ways to better understand transnational law, one could also look at the existing differences between public law and private law. When it comes to the exercise of private power, there is an absence of the kind of constitutional and legal scrutiny and inquiry found in public law. ${ }^{63}$ To put it in the most general terms, public law is rightly subject to a constitutional order because those who are involved in its administration are in their positions by virtue of democratic ideals. The same goes for public international law; states act within treaty or norm standards, which dictate the limits of their powers. On the other hand, in private law the relationship is not umpired under the same rubric of accountability and transparency. De Búrca ${ }^{64}$ thus contends that decision-making beyond the state should not be assessed by the standards of democratic legitimacy. To the extent that transnational law involves many other actors outside of the state, it must not be subjected to the same standards as those of public law. ${ }^{65}$

If we accept the above as true, then one could argue that transnational law is coming of age:

[F]irst I want to examine the 'space' of transnational law. When we take a look at what is 'out there', we see a rich and complex set of relationships, overlapping competencies, and dialogues among states, state entities, international organisations, and non-governmental organisations. Some of these spaces are occupied by institutions creating hard law (such as the World Trade Organization) that purport to bind member nations. Other spaces are sites where a number of national (and sometimes supranational norms) compete. ${ }^{66}$

Based on Aleinikoff's postulation, transnational law has its own distinct space outside of state laws and international law. In fact, a number of scholars agree with this. For example, Calliess ${ }^{67}$ presents the argument that transnational commercial law "constitutes a third category of law beyond the

63 De Búrca 2008 Colum J Transnat'l L 110. Also see Aleinikoff 2008 Yale J Int'l L 488, where the author argues that legal development in transnational spaces is different from how we think of law (and how it is made) and that one of the reasons is that we have not as yet developed a legitimacy story to apply to transnational norms.

64 De Búrca 2008 Colum J Transnat'I L 110.

65 An extension of this argument is that in most cases, there would be a constitution from which the public law ideals are derived, whereas in the transnational space no transnational constitution is available. As such, if democratic legitimacy, as is expected under public law, is imputed to the assessment of transnational law, on which constitution are those ideals based?

66 Aleinikoff 2008 Yale J Int'l L 484.

67 Calliess 2007 Ind J Global Legal Stud 476. 
traditional dichotomy of national and international law." Along similar lines, Capuzzo ${ }^{68}$ argues that:

The global legal order is essentially an order of international networks and organizations, a set of transnational regimes connected and intertwined with each other. In this sense, the global legal order and the transnational regimes that sustain it are something different from both public and international law. It is possible to conceive this complex of transnational regimes as a legal system, or as a set of different and strictly connected legal systems.

This clearly supports the view that any transnational legal system is possibly autonomous from the state and international law, as it does not fit wholly into them. Transnational law could thus be perceived to occupy its own normative space (although this space arises as a result of a gradual accumulation of decisions by both the state and the international order), creating scholarly enterprises like "transnational labour law", "transnational commercial law" and "transnational environmental law", to name a few. ${ }^{69}$ Looking at these enterprises, it seems that the existence of forms of transnational law suggests that there is a "felt need" for regulation, which implies that the problems that are addressed through transnational governance are "not adequately addressed by state-based and local decision-making"70 or regional and international decision-making. Admittedly, issues of legitimacy will always attach to these forms transnational law, and issues related to how they can be enforced will persist. ${ }^{71}$ In view of these potential concerns, transnational law could be better understood as a model complementary to traditional state and international law, as is the case with transnational environmental law. ${ }^{72}$

\section{The example: transnational environmental law}

\subsection{Environmental law in a transnational context}

Why should we think about environmental issues in a transnational context? Why is transnationality important? There are a number of reasons. To start

68 Capuzzo 2013 CLR 3.

69 Also see Cremades and Plehn 1984 BU Int'I L J 321, 324. The authors note that any transnational legal order existing outside the nation state is autonomous from rather than independent of national control.

70 De Búrca 2008 Colum J Transnat'I L 104.

71 It is probably necessary at this point to state that transnational forms of law could be understood as soft law is. While not binding, soft law creates principles that are often adopted by states and at times considered binding by states. In a forthcoming study, we show that courts in Kenya and South Africa are increasingly considering soft law principles derived from the Rio Declaration: United Nations Conference on the Environment and Development (1992) and the Stockholm Declaration: United Nations Conference on the Human Environment (1972) in their decisions. See Soyapi and Kotze "African Courts" (forthcoming 2021).

72 See the further discussion below on transnational climate law and governance. 
with, it is increasingly becoming limiting to think of the geography of law as national, regional or international in nature as there are now various nonstate actors that exercise different regulatory roles (which they do because they are not constrained by issues of sovereignty and state interest). ${ }^{73}$ For instance, organisations like the World Bank and the International Monetary Fund (IMF) have been prioritising environmental concerns, and we see that environmental norms and principles are now being tied to their aid and their conditions for receiving funding. The Equator Principles, for example, arose through the need for the inclusion and recognition of the environmental, social, health and safety standards where private banks provide funding for socio-economic development. ${ }^{74}$ Adopted by banks as private and non-state actors, the principles are voluntary but prescriptive in that they provide the basis for policies and actions aimed at reducing the negative environmental and social impacts of development projects. ${ }^{75}$

The growing communication networks that are largely a product of globalisation have also been exercising non-state actor influence and transnationality. There has been an increase in technological advancements over the last decade with various social media now to the fore, and with the term "social network" gaining popularity. ${ }^{76}$ Instead of people learning about environmental disasters like oil spillages from news channels or even printed newspapers that are issued at designated times, people become aware of environmental concerns instantaneously because of the "quick nature" of Facebook and Twitter posts. ${ }^{77}$ Accordingly, the internet has become popular and crucial for environmental law, with some scholars noting that "the contemporaneous rise of environmentalism and the internet in the mid-late 1990s was not coincidental." ${ }^{178}$ These communication networks facilitated by the internet have also enhanced the spread of environmental activism, which more often takes the form of online campaigns with much more contentious information being disseminated than that which people can get from official state sources. ${ }^{79}$ With this

73 Scholtz 2007 SAYIL 247. Also see Pattberg "Partnerships for Sustainability" 175, where it is indicated that the view that international relations are based on a statecentred ontology can no longer be sustained, since non-state actors of all kinds have been increasing influential.

Ong 2010 Nord J Int'l L 37.

Ong 2010 Nord J Int'l L 39.

Twitter, Facebook and online websites.

Lambert Environmental Law NGOs 8.

Sullivan and Xie 2009 China Q 423.

7 Sullivan and Xie 2009 China Q 425; Lambert Environmental Law NGOs 8. One scholar notes that the use of the social media also enhances the meeting and linking of people and groups with shared interests and relevant causes. See Matthews 2011 http://www.thegreenmarketoracle.com/2011/02/social-media-marketing-and.html. 
internet-based phenomenon of communication, it is not states inter se at play here, but people, groups of people ${ }^{80}$ and non-state actors that are linked in a web of communication that is not national but transnational in nature.

The environmental problems the world faces today are of such a nature that the national and international spaces might not be enough for regulatory purposes. ${ }^{81}$ As far back as 1989 , Sands ${ }^{82}$ stated that "[t]he recognition by governments that environmental issues transcend national boundaries" was accompanied by the realisation that ad hoc and disparate responses by individual states will not solve these pressing problems. Climate change, for instance, is an issue that affects the globe as a whole. ${ }^{83}$ Thus, the extent to which issues arise in one jurisdiction resulting in regulatory responses which might emanate from the regional or the supranational only shows how borders could become increasingly ignored in the future in environmental matters: "[a]gainst the long history of law, global environmental change is a new and complex problem for which we are fashioning a new legal regime. It is the new frontier of environmental law."84

Related to this last point, the problematic nature of environmental regulation through international environmental law is worrisome. To think of international environmental law entirely outside the state is questionable. This is because states are the primary instigators of international environmental law and they drive its development and effectiveness. ${ }^{85}$ To be sure, international environmental law's objectives cannot be achieved without domestic implementation that is dependent on states. ${ }^{86}$ Not only is the process of negotiating treaties and customs slow, but the treaties and customs themselves usually do not offer much, as they often produce weak standards. ${ }^{87}$ This is particularly true when one considers that international agreements are usually a matter of compromise, and some states do not

80 The growth of these networks is enhanced by the existence of think tanks, especially epistemic communities that have wide networks of communication.

81 See Kotzé, who comments that environmental problems are not only global and reciprocally interconnected, but are also becoming unpredictable. Kotzé 2014 SALJ 562.

82 Sand 1989 Harv Int'l L J 393.

83 Faure "Globalisation and the Multi-level Governance" 388. Also see Sand 1989 Harv Int'I L J 393.

Wiener 2001 Ecology L Q 1296.

85 Shaffer and Bodansky 2012 TEL 33. Also see Boyd 2010 U Pa J Int'l L 505, where it is observed that there is a state-centric approach to international environmental law.

86 In some instances, transnational environmental law is also dependent on state efforts.

87 Shaffer and Bodansky 2012 TEL 32. 
even subscribe to the agreements. ${ }^{88}$ This has resulted in one author arguing that multilateral agreements are not the appropriate solution, given that consent is usually attracted by the provision of incentives for participation, which often results in rules and standards that reflect the lowest common denominator. ${ }^{89}$ In contrast, transnational environmental law can exist outside state agreement as it consists of diverse norms that apply in a broader geographical sense than international environmental law. ${ }^{90} \mathrm{~A}$ good example is that of the International Organization for Standardization (ISO) 14001 which, although not hard law, has sought to and continues to influence behaviour. ${ }^{91}$ Thus, even though states could play a role in facilitating the growth and spread of transnational environmental law, the reach of transnational environmental law is beyond states and can apply extensively to organisations and companies (non-state actors). ${ }^{92}$

\subsection{Understanding transnational environmental law}

If international environmental law is considered to be relatively new and constantly changing, ${ }^{93}$ as it is, then transnational environmental law is even more recent and can be described as a young and continuously "emergent system". ${ }^{94}$ To illustrate this, after seven editions of their book Environmental Law, Bell, McGillivray and Pedersen ${ }^{95}$ only recently, in their latest edition, acknowledged transnational environmental law as a distinct body of law and as a source of environmental law. In addition, a new journal titled Transnational Environmental Law was launched a few years ago. ${ }^{96}$ This demonstrates that transnational environmental law is no longer a theoretical

88 The end result in international environmental law is rarely the initially envisioned goal, as by the time treaties are ratified, compromises would have been made.

89 Lin 2013 http://hdl.handle.net/10722/185528.

90 Shaffer and Bodansky 2012 TEL 33. In addition, Bell, Macgillivray and Pedersen note that transnational environmental law has the advantage that it does not have the vagueness and problems relating to enforceability that international environmental law has, since the rules of transnational environmental law are adopted as national laws. See Bell, Macgillivray and Pedersen Environmental Law 87. Also see section 3.5 below for the discussion of the meaning of "law" in transnational environmental law.

91 Also see the brief discussion of ISO standards in section 3.5.2.2 below.

92 Kotzé notes in this regard that global environmental law discards the idea that it is derived exclusively from states. Kotzé 2014 SALJ 571.

93 Turner Substantive Environmental Right 6; Kotzé 2014 SALJ 549. Also see Driesen 2006 ANNALS AAPSS 253, where it is noted that modern environmental law came into being in the 1970s.

94 Yang and Percival 2009 Ecology L Q 617; Kotzé 2014 SALJ 566. Also see Heyvaert and Etty 2012 TEL 7, who state that although transnational environmental law may have grown out of its earliest stages of infancy, it is still in the process of finding itself.

95 Bell, Macgillivray and Pedersen Environmental Law 87.

96 The website of the journal is 2020 https://www.cambridge.org/ core/journals/transnational-environmental-law. It is published by Cambridge University Press and its first edition was in 2012. 
concept only but a fast developing body of law that increasingly demands the attention of scholars.

Sands ${ }^{97}$ suggests that transnational environmental law operates below "the level of visibility of classical public international law" and its rules relate to both the international and national legal order; to public inter-state relations and even to issues of private international law and procedure. Similarly, $K_{\text {Kotzé }}^{98}$ notes that transnational environmental law is "simultaneously national, inter-national (between and across domestic jurisdictions), regional, and international (supranational), and ... it emanates from multiple state and non-state actors variously situated at all of these levels." This formulation suggests that transnational environmental law is wide in scope and like its parent concept, transnational law, exists and operates within, in between and beyond borders. It invites us to look at transnational environmental law as a flexible and reactive body of law that is easily susceptible to change. Consequently, in the same way that transnational law is non-static and dynamic, transnational environmental law is reactive ${ }^{99}$ and concerns the manner and extent to which environmental law responds to the global nature of present-day environmental problems. ${ }^{100}$

\subsection{Transnational climate law and governance}

As noted in the introduction to this paper, I have attempted in earlier works ${ }^{101}$ to demonstrate that the right to a healthy environment is perhaps one clear example of how transnationalism in law is happening. In the absence of the right to a healthy environment at the global level, non-state actors have long been advocating its constitutionalisation in national constitutions. Such constitutionalisation is happening fast through transnational juridical processes of transplantation, convergence of laws, integration and harmonisation; networking and judicial comparative borrowing. ${ }^{102}$ Yet one of the clearest examples of transnational processes at play is the rapid development of transnational climate law and governance initiatives.

Climate change is perhaps the biggest global environmental threat of our time. Global legal developments, however, do not seem to move fast

\section{Sand Transnational Environmental Law 35.}

Kotzé 2014 SALJ 568.

99 Although international environmental law is also reactive to environmental issues, it is quite slow, as noted below under section 3.3.

100 Heyvaert and Etty 2012 TEL 3.

101 See Soyapi "Emerging Transnationality of Environmental Rights" and Kotzé and Soyapi "Transnational Environmental Law".

102 See the general discussion of these processes in Soyapi "Emerging Transnationality of Environmental Rights" and Kotzé and Soyapi "Transnational Environmental Law". 
enough to deal with the threat of climate change. The multilateral environmental agreement space which is dominated by states has produced the United Nations Framework Convention on Climate Change, ${ }^{103}$ the Kyoto Protocol ${ }^{104}$ and more recently, the Paris Agreement. ${ }^{105}$ While instructive and representative of global concerns, there is an acceptance that these frameworks are not adequate to address climate change issues. ${ }^{106}$ Against this backdrop of state-led initiatives, transnational climate law and governance initiatives have risen to become not only:

\begin{abstract}
... a means of supporting and diffusing the implementation of climate-related policies and practices at various governance levels and by non-state actors, but they are also a response to the apparent incapacity of the multilateral climate change regime to address the growing urgency of climate change and to adapt to the changing circumstances of the world. Thus, there is a clear trend away from purely intergovernmental policy making and towards a governance system that incorporates public and private actors at all levels into norm setting, policy making and norm implementation. ${ }^{107}$
\end{abstract}

This clearly accords with the descriptions of transnational law noted earlier in this paper. There is a movement of initiatives beyond the state, ${ }^{108}$ without necessarily an erosion of the state. Such initiatives can be found in climate adaptation measures, climate funding, cities networks etc. ${ }^{109}$ Thus, transnational climate law and governance initiatives are the product of something like a bottom-up approach, in that non-state actors and the private sector are driving the creation of regulatory norms which could then filter into individual states.

\title{
6 Conclusion
}

This article has attempted to stitch together ideas gleaned from an array of scholarship pertaining to transnational law in order to make out a coherent case for its relevance as a scholarly enterprise. The literature shows that it is now clear that because of global change, the idea of the state's complete dominance in law-making is fast diminishing and the notion of a nation, to borrow Venter's ${ }^{110}$ phrase, is "becoming frayed at the edges". The state has become open or cosmopolitan, as the $20^{\text {th }}$ and $21^{\text {st }}$ centuries have generated a wave of globalisation that has influenced virtually all forms of law and governance. While this does not signify the beginning of the end of

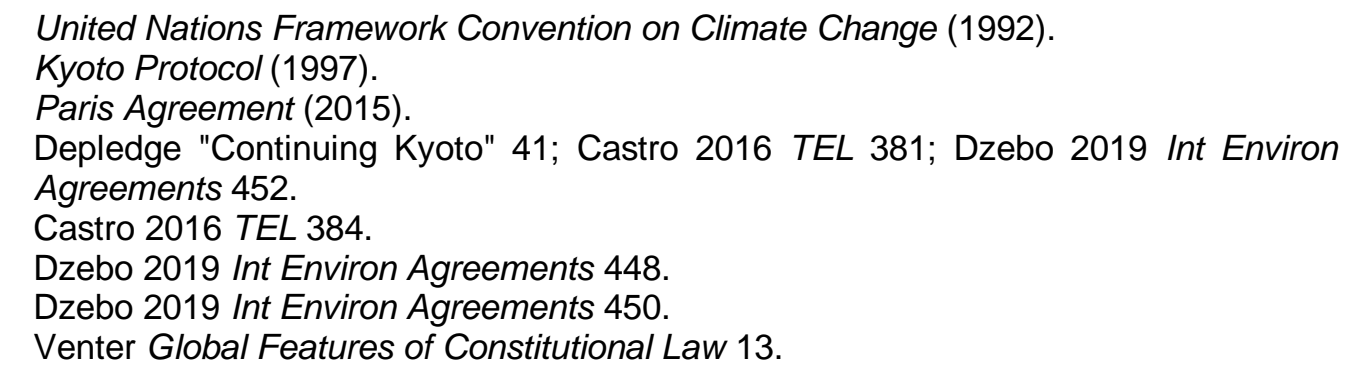


Westphalian sovereignty and the continued existence of the nation state, any modern map of the law that does not include such emerging orders is leaving out too much. ${ }^{111}$

In an environment where international agreement on many concerns usually drags on interminably and is beset by various challenges (like the low standards produced in environmental treaties), ${ }^{112}$ the transnationality of regulation could be a welcome innovation. This is particularly true when one considers that once an agreement is reached and codified, changing it might prove even more difficult than reaching the agreement in the first place. ${ }^{113}$ As they are not national, "transnational rules stand a better chance not to reflect the outdated rules which may still be found in certain legal systems". ${ }^{114}$ Accordingly, transnational law-making is inevitable. In fact, transnational law-making is a practical problem-solving and sense-making process which "illuminates how the by-products of professional problem solving gradually accumulate into non-binding legal rules." 115 In other words, transnational law-making is inevitable in a fluid and ever-changing society, which demands answers and solutions to the increasing problems brought about by and through globalisation. Transnational law represents the totality of norms and rules operating on a global scale and represents the interaction between the national, regional and international systems. It represents a compromise between the conservative nation state lawmaking process and the rigid process of creating international law. To be sure, transnational law has been fast developing over the last 60 years or so. Evidence of its remarkable growth includes the existence of many journals that are now based on transnational law, ${ }^{116}$ as well as academic

111 See Twining, who observes that a modern legal map cannot afford to leave out forms of indigenous, or customary laws, religious laws and also emerging orders like the new lex mercatoria, among others. Twining "Implications of 'Globalisation' for Law as a Discipline" 47.

112 These could be many. For instance, some states might abstain from treaties while others may make reservations. Yet others will flatly refuse.

113 Two scholars have expressed the following opinion: "States face increasing difficulties negotiating and bringing into force multilateral treaties, especially treaties on subjects of universal ambit. For a host of reasons-from bureaucratic inertia to opposition from powerful interest groups-states are refusing to ratify international conventions, even when they accept the legal rights and obligations at issue .... Indeed, even the successful codification of international law brings its own problems; once codified, the law cannot readily evolve to respond to the changing world." Brower and Sharpe 2004 Va J Int'I L 201.

114 Gaillard 2001 Arb Int'l 61.

115 Quack 2007 Organization 644.

116 Some of the journals include Columbia Journal of Transnational Law, Journal of Transnational Law, Journal of Transnational Law and Policy, Transnational Legal Theory, Transnational Law Review and more recently the journal of Transnational Environmental Law. 
qualifications dealing with transnational law. ${ }^{117}$ It already has a corpus of law to its name, and is no longer abstract but can be taxonomically identified.

\section{Bibliography}

\section{Literature}

Aleinikoff 2008 Yale J Int'l L

Aleinikoff TA "Transnational Spaces: Norms and Legitimacy" 2008 Yale J Int'l L 479-490

Bell, Macgillivray and Pedersen Environmental Law

Bell S, Macgillivray D and Pedersen O Environmental Law (Oxford University Press London 2013)

Berman "Introduction"

Berman PS "Introduction" in Berman PS (ed) The Globalization of International Law (Ashgate Aldershot 2005) xiv-xlviii

Bernal 2011 New Polit Sci

Bernal AM "Power, Powerlessness and Petroleum: Indigenous Environmental Claims and the Limits of Transnational Law" 2011 New Polit Sci $143-167$

Black Black's Law Dictionary

Black HC Black's Law Dictionary (West St Paul 1968)

Boyd 2010 U Pa J Int'I L

Boyd W "Climate Change, Fragmentation, and the Challenges of Global Environmental Law: Elements of a Post-Copenhagen Assemblage" $2010 \mathrm{U}$ Pa J Int'I L 457-550

Brouder "Philip Jessup"

Brouder A "Philip Jessup: The Original Transnational Lawyer" in Tietje C, Brouder A and Nowrot K (eds) Philip C Jessup's Transnational Law Revisited - On the Occasion of the $50^{\text {th }}$ Anniversary of its Publication (Institut fur Wirtschaftsrecht Halle 2006) 7-15

117 Among the many qualifications, there is a Master of Laws (LLM) in Transnational Legal Studies at the University of Amsterdam; LLM in Transnational Law at King's College London; LLM Transnational Law at the University of Bremen; a graduate degree in US and Transnational Law for Foreign Lawyers at the University of Miami; LLM Transnational Law at Temple University and an LLM in Transnational Law at the University of Oldenburg. 
Brower and Sharpe 2004 Va J Int'l L

Brower CN and Sharpe JK "The Creeping Codification of Transnational Commercial Law: An Arbitrator's Perspective" 2004 Va J Int'l L 199-221

Burley 1993 AJIL

Burley AS "International Law and International Relations Theory: A Dual Agenda" 1993 AJIL 205-239

Calliess 2007 Ind J Global Legal Stud

Calliess G "The Making of Transnational Contract Law" 2007 Ind J Global Legal Stud 469-483

Capuzzo 2013 CLR

Capuzzo G "Legal Expertise: On Some Uses of Law in Transnational Regimes" 2013 CLR 1-19

Castro 2016 TEL

Castro P "Common but Differentiated Responsibilities Beyond the Nation State: How is Differential Treatment Addressed in Transnational Climate Governance Initiatives?" 2016 TEL 379-400

Cotterrell 1997 Can J L \& Soc'y

Cotterrell R "A Legal Concept of Community" 1997 Can J L \& Soc'y 75-91

Cotterrell 2012 Law Soc Inq

Cotterrell R "What is Transnational Law?" 2012 Law Soc Inq 500-524

Cranston 2007 Tex Int'l L J

Cranston R "Theorizing Transnational Commercial Law" 2007 Tex Int'l L J 597-617

Cremades and Plehn 1984 BU Int'l L J

Cremades BM and Plehn SL "The New Lex Mercatoria and the Harmonization of the Laws of International Commercial Transactions" 1984 BU Int'l L J 317-348

De Búrca 2008 Colum J Transnat'l L

De Búrca G "Developing Democracy beyond the State" 2008 Colum J Transnat'l L 101-158

De Garay 1941 Notre Dame Law

De Garay L "What is Law?" 1941 Notre Dame Law 261-297

Depledge "Continuing Kyoto"

Depledge J "Continuing Kyoto: Extending Absolute Emission Caps to Developing Countries" in Baumert KA (ed) Building on the Kyoto Protocol: 
Options for Protecting the Climate (World Resources Institute Washington DC 2002) 31-60

Dibadj 2008 Stan J Int'I L

Dibadj R "Panglossian Transnationalism" 2008 Stan J Int'l L 253-299

Driesen 2006 ANNALS AAPSS

Driesen D "Environmental Protection, Free Trade, and Democracy" 2006 ANNALS AAPSS 252-261

Dzebo 2019 Int Environ Agreements

Dzebo A "Effective Governance of Transnational Adaptation Initiatives" 2019 Int Environ Agreements 447-466

Faure "Globalisation and Multi-level Governance"

Faure M "Globalisation and Multi-level Governance of Environmental Harm" in Faure M and Van der Walt A (eds) Globalization and Private Law: The Way Forward (Edward Elgar Cheltenham 2010) 383-425

Gaillard 2001 Arb Int'I

Gaillard E "Transnational Law: A Legal System or a Method of Decision Making?" 2001 Arb Int'l 59-71

Goode 1997 Int Comp L Q

Goode R "Usage and its Reception in Transnational Commercial Law" 1997 Int Comp L Q 1-36

Gopalan 2003 Am U Int'l L Rev

Gopalan S "Transnational Commercial Law: The Way Forward" 2003 Am U Int'I L Rev 803-849

Hathaway 2005 U Chi L Rev

Hathaway OA "Between Power and Principle: An Integrated Theory of International Law" 2005 U Chi L Rev 469-536

Heyvaert and Etty 2012 TEL

Heyvaert V and Etty T "Introducing Transnational Environmental Law" 2012 TEL 1-11

Hund 2004 SAPL

Hund J "Globalisation and the Rule of Law: Socio-economic Reflections" 2004 SAPL 25-45

Jessup Transnational Law

Jessup PC Transnational Law (Yale University Press New Haven 1956) 
Karton 2012 Tilburg L Rev

Karton J "Global Law: The Spontaneous, Gradual Emergence of a New Legal Order" 2012 Tilburg L Rev 276-284

Koh 1996 Neb L Rev

Koh HH "The 1994 Roscoe Pound Lecture: Transnational Legal Process" 1996 Neb L Rev 181-207

Koh 2006 Penn St Int'l L Rev

Koh HH "Why Transnational Law Matters" 2006 Penn St Int'l L Rev 745-753

Kotzé Global Environmental Governance

Kotzé LJ Global Environmental Governance: Law and Regulation for the $21^{\text {st }}$ Century (Edward Elgar Cheltenham 2012)

Kotzé 2014 SALJ

Kotzé LJ "Fragmentation Revisited in the Context of Global Environmental Law and Governance" 2014 SALJ 548-582

Kotzé and Soyapi "Transnational Environmental Law"

Kotzé LJ and Soyapi CB "Transnational Environmental Law: The Birth of a Contemporary Analytical Perspective" in Douglas Fisher (ed) Research Handbook on Fundamental Concepts of Environmental Law (Edward Elgar Cheltenham 2016) 82-110

Kronke 2005 Loy L Rev

Kronke $\mathrm{H}$ "Methodical Freedom and Organizational Constraints in the Development of Transnational Commercial Law" 2005 Loy L Rev 287-299

Lambert Environmental Law NGOs

Lambert K Environmental Law NGOs and Social Media Use: An Analysis of Strategies and Organizational Impacts (Honors-thesis University of Michigan 2014)

Larouche and Cserne "Conclusions"

Larouche $\mathrm{P}$ and Cserne $\mathrm{P}$ "Conclusions" in Larouche $\mathrm{P}$ and Cserne $\mathrm{P}$ (eds) National Legal Systems and Globalization (Asser The Hague 2013) 371384

Maniruzzaman 1999 Am U Int'l L Rev

Maniruzzaman AFM "The Lex Mercatoria and International Contracts: A Challenge for International Commercial Arbitration?" 1999 Am U Int'l L Rev 657-734 
Menkel-Meadow 2011 UC Irvine L Rev

Menkel-Meadow C "Why and How to Study Transnational Law" 2011 UC Irvine L Rev 97-129

Michaels 2007 Ind J Global Legal Stud

Michaels R "The True Lex Mercatoria: Law beyond the State" 2007 Ind J Global Legal Stud 447-468

Nina and Scharf "Introduction"

Nina D and Scharf W "Introduction: The Other Law?" in Scharf W and Nina D (eds) The Other Law: Non-state Ordering in South Africa (Juta Lansdowne 2001) 1-13

Ong 2010 Nord J Int'l L

Ong DM "From 'International' to 'Transnational' Environmental Law? A Legal Assessment of the Contribution of the 'Equator Principles' to International Environmental Law" 2010 Nord J Int'l L 35-74

Pattberg "Partnerships for Sustainability"

Pattberg $P$ "Partnerships for Sustainability: An Analysis of Transnational Environmental Regimes" in Glasbergen P, Bierman F and Mol APJ (eds) Partnerships, Governance and Sustainable Development: Reflections on Theory and Practice (Edward Elgar Cheltenham 2007) 173-193

Perez 2003 Ind J Global Legal Stud

Perez O "Normative Creativity and Global Legal Pluralism: Reflections on the Democratic Critique of Transnational Law" 2003 Ind J Global Legal Stud 25-64

Quack 2007 Organization

Quack S "Legal Professionals and Transnational Law-Making: A Case of Distributed Agency" 2007 Organization 643-666

Sand 1989 Harv Int'l L J

Sand PH "The Environment, Community and International Law" 1989 Harv Int'l L J 393-420

Sand Transnational Environmental Law

Sand PH Transnational Environmental Law: Lessons in Global Change (Kluwer Law International The Hague 1999)

Scholtz 2007 SAYIL

Scholtz W "Northern NGOs, Southern NGOs and International Environmental Law: The Common Interest of Humankind is the Interest of Northern Mankind!" 2007 SAYIL 247-260 
Scott 2009 Ger Law J

Scott C "'Transnational Law' as a Proto-concept: Three Conceptions" 2009 Ger Law J 859-876

Shaffer and Bodansky 2012 TEL

Shaffer $G$ and Bodansky D "Transnationalism, Unilateralism and International Law" 2012 TEL 31-41

Shams 2001 Int'l Law

Shams H "Law in the Context of 'Globalisation': A Framework of Analysis" 2001 Int'l Law 1589-1626

Soyapi "Emerging Transnationality of Environmental Rights"

Soyapi CB "The Emerging Transnationality of Environmental Rights" in Daly $\mathrm{E}$ et al (eds) New Frontiers in Environmental Constitutionalism (UNEP Nairobi 2017) 270-279

Soyapi and Kotze "African Courts"

Soyapi CB and Kotze LJ "African Courts and Principles of International Environmental Law: A Kenyan and South African Case Study" (forthcoming 2021)

Sullivan and Xie 2009 China $Q$

Sullivan $\mathrm{J}$ and Xie $\mathrm{L}$ "Environmental Activism, Social Networks and the Internet" 2009 China Q 422-432

Sutherland "Globalization and Corporate Law"

Sutherland $\mathrm{P}$ "Globalization and Corporate Law" in Faure M and Van der Walt A Globalization and Private Law: The Way Forward (Edward Elgar Cheltenham 2010) 255-340

Teubner 2002 Eur J Soc Theory

Teubner G "Breaking Frames: Economic Globalization and the Emergence of Lex Mercatoria" 2002 Eur J Soc Theory 199-217

Tietje and Nowrot "Laying Conceptual Ghosts of the Past to Rest" Tietje C and Nowrot K "Laying Conceptual Ghosts of the Past to Rest: The Rise of Philip C. Jessup's 'Transnational Law' in the Regulatory Governance of the International Economic System" in Tietje C, Brouder A and Nowrot K (eds) Philip C Jessup's Transnational Law Revisited - On the Occasion of the $50^{\text {th }}$ Anniversary of its Publication (Institut fur Wirtschaftsrecht Halle 2006) 17-44 
Turner Substantive Environmental Right

Turner S A Substantive Environmental Right: An Examination of the Legal Obligations of Decision-makers towards the Environment (Kluwer Law International The Hague 2009)

Twining "Implications of 'Globalisation' for Law as a Discipline"

Twining W "Implications of 'Globalisation' for Law as a Discipline" in Halpin A and Roeben V (eds) Theorising the Global Legal Order (Hart Portland 2009) 39-59

Venter Global Features of Constitutional Law

Venter F Global Features of Constitutional Law (Wolf Legal Nijmegen 2020)

Wiener 2001 Ecology L Q

Wiener JB "Something Borrowed for Something Blue: Legal Transplants and the Evolution of Global Environmental Law" 2001 Ecology L Q 12951371

Yang and Percival 2009 Ecology $L Q$

Yang $T$ and Percival RV "The Emergence of Global Environmental Law" 2009 Ecology L Q615-664

International instruments

Kyoto Protocol (1997)

Paris Agreement (2015)

Rio Declaration: United Nations Conference on the Environment and Development (1992)

Rome Statute of the International Criminal Court (1998)

Stockholm Declaration: United Nations Conference on the Human Environment (1972)

United Nations Framework Convention on Climate Change (1992)

\section{Internet sources}

Backer 2007 http://lcbackerblog.blogspot.com/2007/03/principles-oftransnational-law.html

Backer LC 2007 Principles of Transnational Law: The Foundations of an Emerging Field http://lcbackerblog.blogspot.com/2007/03/principles-oftransnational-law.html accessed 13 November 2014

Berman 2005 https://papers.ssrn.com/sol3/papers.cfm?abstract id $=666143$ 
Berman H 2005 World Law: An Ecumenical Jurisprudence of the Holy Spirit - Emory University School of Law Public Law and Legal Theory Research Paper Series Research Paper No 05-4 https://papers.ssrn.com/sol3/papers.cfm?abstract_id=666143 accessed 3 October 2020

Cambridge University Press 2020 https://www.cambridge.org/core/ journals/transnational-environmental-law

Cambridge University Press 2020 Transnational Environmental Law https://www.cambridge.org/core/journals/transnational-environmental-law accessed 3 October 2020

Lin 2013 http://hdl.handle.net/10722/185528

Lin JSW 2013 Transnational Environmental Law in Action: The European Union's Sustainable Biofuels Experiment http://hdl.handle.net/ 10722/185528 accessed 12 February 2015

Matthews 2011 http://www.thegreenmarketoracle.com/2011/02/socialmedia-marketing-and.html

Matthews R 2011 Social Media Marketing and Environmental Sustainability http://www.thegreenmarketoracle.com/2011/02/social-media-marketingand.html accessed 20 June 2015

Mendenhall 2011 https://www.researchgate.net/publication/228227762_ Transnational_Law_An_Essay_in_Definition_with_a_Polemic_Addendum Mendenhall AP 2011 Transnational Law: An Essay in Definition with a Polemic Addendum https://www.researchgate.net/publication/228227762_ Transnational_Law_An_Essay_in_Definition_with_a_Polemic_Addendum accessed 3 October 2020

Michaels 2009 http://ssr.nellco.org/duke_fs/185

Michaels R 2009 Global Legal Pluralism Duke Law School Faculty Scholarship Series Paper 185 http://lsr.nellco.org/duke_fs/185 accessed 12 December 2012

Zumbansen 2011 https://digitalcommons.osgoode.yorku.ca/cgi/view content.cgi?article $=1065 \&$ context $=$ clpe

Zumbansen P 2011 Transnational Law, Evolving - Osgoode Comparative Research in Law and Political Economy Research Paper No 27 https://digitalcommons.osgoode.yorku.ca/cgi/viewcontent.cgi?article $=1065$ \&context=clpe accessed 3 October 2020

Zumbansen $2011 \quad$ https:/www.wzb.eu/system/files/docs/tsr/cgc/ zumbansen2012definingthespaceoftransnationallawwzbhu.pdf 
Zumbansen P 2011 Defining the Space of Transnational Law: Legal Theory, Global Governance and Legal Pluralism - Osgoode CLPE Research Paper No 21 https://www.wzb.eu/system/files/docs/tsr/cgc/zumbansen 2012definingthespaceoftransnationallawwzbhu.pdf accessed 3 October 2020

\section{List of Abbreviations}

AJIL

Am U Int'I L Rev

ANNALS AAPSS

Arb Int'l

BU Int'l L J

Can J L \& Soc'y

China $Q$

CLR

Colum J Transnat'I L

Ecology L Q

Eur J Soc Theory

Ger Law J

Harv Int'l L J

Ind J Global Legal Stud

Int Comp L Q

Int Environ Agreements

Int'I Law

LA Legal Notes

Law Soc Inq

Loy L Rev

Neb L Rev

New Polit Sci

Nord J Int'I L

Notre Dame Law

Penn St Int'I L Rev

SALJ

SAPL

SAYIL
American Journal of International Law

American University International Law Review

ANNALS of the American Association of Political and Social Science

Arbitration International

Boston University International Law Journal

Canadian Journal of Law and Society

The China Quarterly

Comparative Law Review

Columbia Journal of Transnational Law

Ecology Law Quarterly

European Journal of Social Theory

German Law Journal

Harvard International Law Journal

Indiana Journal of Global Legal Studies

International and Comparative Law

Quarterly

International Environmental Agreements:

Politics, Law and Economics

The International Lawyer

Libertarian Alliance Legal Notes

Law and Social Inquiry

Loyola Law Review

Nebraska Law Review

New Political Science

Nordic Journal of International Law

Notre Dame Lawyer

Penn State International Law Review

South African Law Journal

Southern African Public Law

South African Yearbook of International Law 
Stan J Int'I L

TEL

Tex Int'I L J

Tilburg L Rev

U Chi L Rev

U Pa J Int'I L

UC Irvine L Rev

Va J Int'I L

Yale J Int'I L
Stanford Journal of International Law

Transnational Environmental Law

Texas International Law Journal

Tilburg Law Review

University of Chicago Law Review

University of Pennsylvania Journal of International Law

UC Irvine Law Review

Virginia Journal of International Law

Yale Journal of International Law 